\title{
Studies on Physico-chemical Analysis of the Raw and Boiled Sorghum
}

\author{
Thutturu Sravan*, Indrajeet Sahu, Swapna Sagarika Sahoo and Mana Nayak \\ Department of Agricultural Processing and Food Engineering, Orissa University of \\ Agriculture and Technology, Bhubaneshwar, Odisha, India \\ *Corresponding author
}

\section{A B S T R A C T}

\begin{tabular}{|l|}
\hline Ke y w o r d s \\
$\begin{array}{l}\text { Sorghum, Physical } \\
\text { properties, Boiled } \\
\text { grains, Cereal and } \\
\text { Moisture content }\end{array}$ \\
\hline Article Info \\
$\begin{array}{l}\text { Accepted: } \\
\text { 12 January } 2021 \\
\text { Available Online: } \\
\text { 10 February } 2021\end{array}$ \\
\hline
\end{tabular}

\section{Introduction}

Sorghum [Sorghum bicolor (L.) Moench] also known as jowar, is the "king of millets" and is the fifth most important cereal in the world after wheat, rice, maize and barley (Anglani, 1998; Awika and Rooney, 2004). The main benefit of sorghum is that it hibernates under adverse conditions and can resume growth after a relatively severe drought. Today the major sorghum growing parts are the Deccan Plateau of North America, Sub-Saharan Africa, Northeast China and Central India, Nigeria, Argentina, Egypt and Mexico (Awika and Rooney, 2004). Sorghum is mostly used as food (55\%), in the form of porridge (thick or thin) and flat breads in Asia and Africa, and as feed (33\%) in the United States (Anonymous, 2012). Sorghum offers a good base for gluten-free products and is safely suggested for celiac patients. So, the upcoming potential of sorghum in the advanced world is a wheat substitute for those with celiac disease or gluten allergy (Bogue and Sorenson, 2008).

Worldwide sorghum production in 2011 was 59.2 million tonnes and planted area was 38.7 million hectares, with an average grain yield of $1527.4 \mathrm{~kg}$ per hectare. In India, sorghum production in 2011-2012 was 6 million tonnes and planted area was 6.3 million hectares, 
with an average grain yield of 0.95 tonnes per hectare (Anonymous, 2013).

Sorghum is an important cereal that is said to be a staple food for the poor in many countries. This grain is similar to corn but contains more fats and proteins. This proves to be good for livestock and is therefore the reason why the crop is so popular as feed. The nutritional value of sorghum is similar to that of maize and hence it is gaining importance as fodder for cattle. Sorghum is used as food and feed material for grain alcohol, ethanol production, flour production, adhesives and paper production. It is also known by different names depending on the geography of Durra, Guinea corn, Jowar, Egyptian millet, Shallu, Juwar, Milo, and Sudan grass. Sorghum grows in a wide range of agricultural environments, especially in moist stressed areas where other crops can at least survive and food insecurity is prevalent.

\section{Materials and Methods}

Sorghum [Sorghum bicolor (L.) Moench] were procured from wholesale market and brought to the laboratory. The physiochemical properties of raw and boiled sorghum seeds were carried at Agro Produce Processing Division (APPD), ICAR- Central Institute of Agriculture Engineering (CIAE), Bhopal, Madhya Pradesh. It is situated in the latitude of $23.3099^{\circ} \mathrm{N}$, longitude of $77.4031^{\circ}$ $\mathrm{E}$ and at an elevation of $495 \mathrm{~m}$ above mean sea level. Necessary chemicals and glass wares required during experiments were used from laboratory.

\section{Physical characteristics of raw and boiled sorghum}

\section{Size (length, width and thickness)}

100 sorghum seeds were taken to determine the size of the sorghum seeds. For each individual seed, there are three main dimensions are length (L), width (W) and thickness (T), measured in $\mathrm{mm}$ using digital vernier calipers with reading accuracy within $0.01 \mathrm{~mm}$.

\section{Geometric Mean Diameter (GMD)}

The seeds to be measured were randomly taken as 100 samples. Size of sorghum seeds is measured in length, thickness and width. The following equation was used to determine the geometric mean diameter of the seeds. The geometric mean diameter (GMD) in $\mathrm{mm}$ is determined using the following expression (Mohsenin, 1986):

$\mathrm{GMD}=(\mathrm{L} \times \mathrm{W} \times \mathrm{T})^{1 / 3}$,

Where $\mathrm{L}=$ length, $\mathrm{mm} ; \mathrm{W}=$ width, $\mathrm{mm}$ and $\mathrm{T}$ $=$ thickness, $\mathrm{mm}$

\section{Arithmetic mean diameter (AMD)}

To determine AMD, 100 samples were taken. By using the length, width and thickness AMD was determined. The arithmetic mean diameter (AMD) in $\mathrm{mm}$ is determined by using the following expression (Mohsenin, 1986):

$$
\mathrm{AMD}=(\mathrm{L}+\mathrm{W}+\mathrm{T}) / 3
$$

\section{Aspect ratio}

To obtain about the sorghum kernel shape, aspect ratio is calculated.

Aspect ratio $=\{\mathrm{W} / \mathrm{L}\} \times 100$

\section{Sphericity}

By using the 3 principal dimensions, we can determine the sphericity. This parameter shows the shape character of particle relative to the sphere. 
Sphericity $=$ Geometric mean diameter $/$ Major intercept $=(\mathrm{LWT})^{1 / 3} / \mathrm{L}$

\section{Bulk density}

Bulk density of grains is measured by standard method which is given by (AOAC, 1990).

\section{True density}

It is well-defined as the ratio of mass of the sample of grains to the solid volume occupied by the sample. It is also called the "particle density". To determining the true density, initially weighed the mass of the grain by using the weighing balance.

Then for measuring the volume of grains $100 \mathrm{ml}$ of toluene was used in the graduated cylinder (Fig. 1) and then placed the grains in the graduated cylinder and the toluene moves the upper portion of the graduated cylinder and the observations are recorded. Averages of three replications were used for calculation.

True density $=$ Mass of the grain $/$ Volume of the toluene displaced

\section{Porosity}

Porosity indicates the number of pores in the bulk material. The percent porosity is calculated on the following relationship (Mohsenin, 1986):

Porosity $=\{($ True density - Bulk density $) /$ (True density) $\} \times 100$

\section{Moisture content determination}

The moisture content of sorghum grain is determined by following AOAC method (AOAC 2005; Method No. 925.10). Moisture content of the sorghum seed were determined by using the standard hot air oven method
(Fig. 2). About $2 \mathrm{~g}$ samples was taken separately in the petri plates and kept in the hot air oven at $105 \pm 1{ }^{\circ} \mathrm{C}$ for $24 \mathrm{~h}$. After drying, the petri dishes containing the dry sample were kept in a desiccator for 10 mins for cooling down the samples. After that the samples were weighed by a weighing balance and the weight is recorded. All the measurement was replicated thrice and the average moisture content was calculated. The moisture content is determined using the following formula:

Moisture content $($ in $\mathrm{db})=\left\{\left(\mathrm{W}_{1}-\mathrm{W}_{2}\right) / \mathrm{W}_{1}\right\} \times$ 100

$\mathrm{W}_{1}=$ Initial weight of the grain, $\mathrm{g}$

$\mathrm{W}_{2}=$ Final weight of the grain, $\mathrm{g}$

\section{Angle of repose}

When a granular material is allowed to flow freely from a point into a pile, the angle made with the horizontal plane towards the pile is called the angle of repose (IS: 6663-1972). Angle of repose is important in designing a structure for storage of food grains in bulk. The apparatus used for measuring angle of repose of samples consisted of a hollow metal box of $93 \times 90 \times 50 \mathrm{~mm}$ size $(\mathrm{L} \times \mathrm{W} \times \mathrm{H})$ and it is mounted on rectangular platform having size of $200 \times 150 \times 130 \mathrm{~mm}$ and a discharge gate at one side of the box. The box was filled with samples and the gate was removed quickly.

The height $(\mathrm{H}, \mathrm{mm})$ of the sample is to be retained on the rectangular plat form inside box was measured and the angle of repose was calculated as given below formulae: (Mohsenin, 1986).

$\theta=\tan ^{-1}(2 \mathrm{H} / \mathrm{D})$

$\mathrm{H}=$ height of cone formed measured with depth gauge, $\mathrm{mm}$ 
$\mathrm{D}=$ diameter of the platform on which the cone formed, $\mathrm{mm}$

\section{Chemical characteristics of raw and boiled sorghum}

Raw and boiled sorghum were analyzed for ash and fat content. All the measurements were replicated thrice and the results were expressed as the average value.

\section{Ash content}

AOAC (1990) method using muffle furnace was used to determined ash content of the samples. The per cent ash was calculated using following formula:

Ash content $(\%)=\left\{\mathrm{Wash} / \mathrm{W}_{\text {initial }}\right\} \times 100$

Where $\mathrm{W}_{\mathrm{ash}}=$ Weight of ash and $\mathrm{W}_{\text {initial }}=$ Initial weight - dry matter

\section{Fat content}

AOAC (1990) method using Soxhlet apparatus was used to determined crude fat content of the samples. The percent of crude fat was expressed as follows:

Fat content $(\%)=\{$ Weight of dried ether soluble material/ Weight of sample $\} \times 100$

\section{Results and Discussion}

This chapter deals with the results of the experiments carried out related to the study. Physical properties such as moisture content $(\mathrm{db} \%)$, size or linear dimensions, arithmetic mean diameter (AMD), geometric mean diameter (GMD), sphericity, aspect ratio, porosity, bulk density, true density and angle of repose were investigated and the mean value of results are tabulated below Table 1 .

Table.1 Physio-chemical properties of sorghum grains

\begin{tabular}{|c|c|c|c|}
\hline \multirow{2}{*}{ S. No } & Properties & \multicolumn{2}{|c|}{ Mean \pm SE } \\
\hline 1 & Length, mm & Raw Sorghum & Boiled Sorghum \\
\hline 2 & Width, mm & $4.42 \pm 0.03$ & $5.71 \pm 0.04$ \\
\hline 3 & Thickness, mm & $3.31 \pm 0.03$ & $4.64 \pm 0.03$ \\
\hline 4 & GMD, mm & $2.57 \pm 0.01$ & $3.75 \pm 0.03$ \\
\hline 5 & AMD, mm & $3.09 \pm 0.01$ & $4.18 \pm 0.02$ \\
\hline 6 & Aspect ratio & $3.17 \pm 0.02$ & $4.46 \pm 0.03$ \\
\hline 7 & Sphericity & $0.57 \pm 0.01$ & $0.71 \pm 0.01$ \\
\hline 8 & True density $\left(\mathrm{Kg} / \mathrm{m}^{3}\right)$ & $0.66 \pm 0.01$ & $0.79 \pm 0.01$ \\
\hline 9 & Bulk density $\left(\mathrm{Kg} / \mathrm{m}^{3}\right)$ & $573.74 \pm 6.34$ & $501.08 \pm 5.37$ \\
\hline 10 & Porosity & $641.37 \pm 6.25$ & $587.31 \pm 5.12$ \\
\hline 11 & Moisture content $(\%)$ & $0.63 \pm 0.00$ & $0.77 \pm 0.01$ \\
\hline 12 & Angle of repose $($ Degrees $)$ & $12.23 \pm 0.02$ & $32.57 \pm 4.12$ \\
\hline 13 & Ash content $(\%)$ & $35^{\circ} 41^{\prime}$ & $42^{\circ} 37^{\prime}$ \\
\hline 14 & Fat content $(\%)$ & $1.87 \pm 0.01$ & $1.36 \pm 0.01$ \\
\hline
\end{tabular}


Fig.1 Measuring the true density by using the toluene

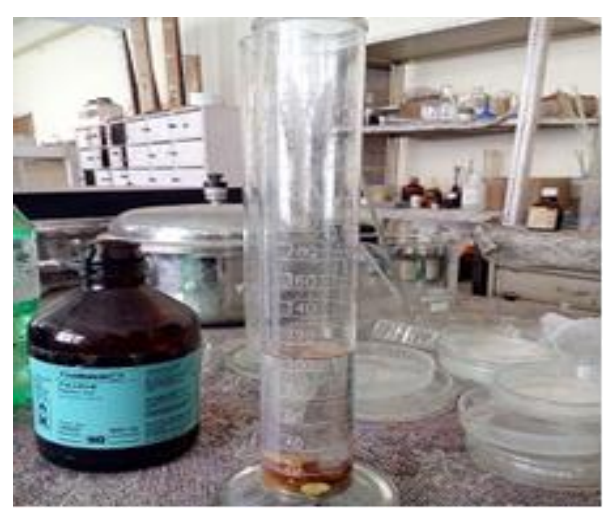

Fig.2 Hot air oven

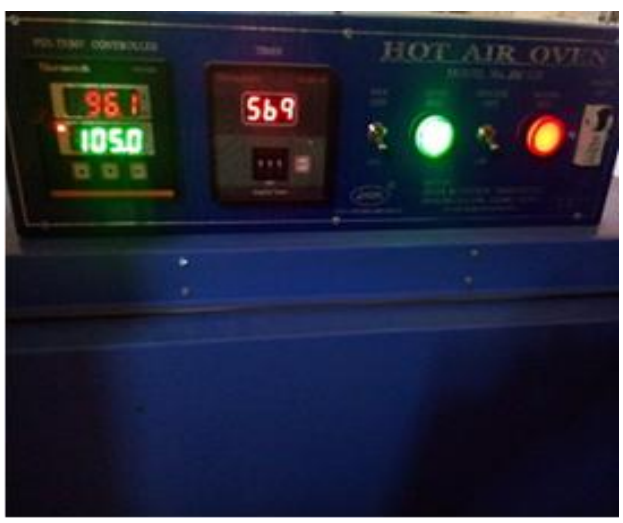

From the Table 1, it was observed that the moisture content of raw sorghum and boiled sorghum were determined to be $12.23 \pm 0.02$, $32.57 \pm 4.12 \%$ respectively. Moisture content of boiled sorghum compared to raw sorghum increased due to boiling of grain. The variation in percent moisture composition might be due to variation in cultivars of the sorghum grains. The linear dimensions or size of the raw sorghum found to be $4.42 \pm 0.03$ $\mathrm{mm}, 3.31 \pm 0.03 \mathrm{~mm}$ and $2.57 \pm 0.01 \mathrm{~mm}$ $5.71 \pm 0.04 \mathrm{~mm} 4.64 \pm 0.03 \mathrm{~mm}$ and $3.75 \pm 0.03$ $\mathrm{mm}$ respectively for boiled sorghum. The bulk density of raw sorghum and boiled sorghum found to be $641.37 \pm 6.25 \mathrm{Kg} / \mathrm{m}^{3}$ and $587.31 \pm 5.12 \mathrm{Kg} / \mathrm{m}^{3}$ respectively. Bulk density of boiled sorghum is decreased as compared to raw sorghum grain may be due to increased moisture content. The variation in percent chemical composition might be due to variation in cultivars. Similar range of percent chemical composition was reported by Chavan et al., (2009).

The present study concluded that all the sorghum contains good source of protein, fiber and had high in fat content. The major variation in the values of physical properties of raw sorghum grain and boiled sorghum may be due to variation in their moisture content.

\section{Acknowledgement}

The authors would like to thank the Agro Produce Processing Division (APPD), ICARCentral Institute of Agriculture Engineering (CIAE), Bhopal, Madhya Pradesh for providing institutional support. 


\section{References}

AOAC. International, 1990. Official methods of analysis. Trends Food Sci. Technology.

AOAC 2005 Official methods of analysis, $18^{\text {th }}$ Edn., Assoc. of Official AnalyticalChemists, Washington, DC.

Anglani, C. (1998). Sorghum for human food: a review. Plant Foods Human Nutrition. 52: 85-89.

Anonymous (2012). ICRISAT report 2012. www.icrisat.org.

Anonymous (2013). Economic Survey of India (2012-13). Statistical Appendix.
Production of Major crops. Government of India. Link: http://indiabudget.nic.in.

Awika, J.M. and Rooney L.W. (2004). Sorghum phytochemicals and their potential aspects on human health. Phytochemistry, 65:1199-1221.

Chavan,U. D., Patil J.V., and Shinde M.S. (2009). Nutritional and Roti quality of sorghum genotypes. Indonesian Journal of Agricultural Science, 10: 80-87.

Mohsenin N N 1986 Physical properties of plantand animal materials $\left(2^{\text {nd }} E d.\right)$, Gordon and Breach Science Publishers, New York, USA. Pp: 63-107.

\section{How to cite this article:}

Thutturu Sravan, Indrajeet Sahu, Swapna Sagarika Sahoo and Mana Nayak. 2021. Studies on Physico-chemical Analysis of the Raw and Boiled Sorghum. Int.J.Curr.Microbiol.App.Sci. 10(02): 1298-1303. doi: https://doi.org/10.20546/ijcmas.2021.1002.153 